\title{
Effect of GLUTI Inhibition and Autophagy Modulation on the Growth and Migration of Laryngeal Carcinoma Stem Cells Under Hypoxic and Low-Glucose Conditions
}

\author{
Xiao-Hong Chen' \\ Jia Liu $^{2}$ \\ Jiang-Tao Zhong ${ }^{2}$ \\ Shui-Hong Zhou (D) ${ }^{2}$ \\ Jun Fan $^{3}$
}

'Department of Otolaryngology, The Second Hospital of Jiaxing (The Second Affiliated Hospital, Jiaxing University), Jiaxing City, Zhejiang Province, 3/4000, People's Republic of China; ${ }^{2}$ Department of Otolaryngology, The First Affiliated Hospital, College of Medicine, Zhejiang University, Hangzhou, Zhejiang, 310003 , People's Republic of China; ${ }^{3}$ State Key Laboratory for Diagnosis and Treatment of Infectious Diseases, The First Affiliated Hospital, College of Medicine, Zhejiang University, Hangzhou, Zhejiang, 310003, People's Republic of China
Correspondence: Shui-Hong Zhou Department of Otolaryngology, The First Affiliated Hospital, College of Medicine, Zhejiang University, 79 Qingchun Road, Hangzhou City, 3 I0003, People's Republic of China

Tel +86-57I-87236894

Fax +86-57I-87236895

Email II90051@zju.edu.cn
Background: Enhanced glucose uptake and autophagy are means by which cells adapt to stressful microenvironments. In this study, we investigated the roles of glucose transporter-1 (GLUT-1) and autophagy in laryngeal carcinoma stem cells under hypoxic and low-glucose conditions.

Materials and Methods: CD133-positive Tu212 laryngeal carcinoma stem cells were purified by magnetic-activated cell sorting and subjected to hypoxic and/or low-glucose conditions. Proliferation was evaluated using a cell-counting kit and a clone-formation assay, and migration capability was measured through a Transwell assay. Autophagy was assessed using transmission electron microscopy. Gene silencing was monitored using shRNA technology and autophagy regulation was manipulated using rapamycin, 3-MA, or chloroquine. Gene expression levels were evaluated by quantitative reverse transcriptionpolymerase chain reaction and protein levels were assessed via Western blotting.

Results: Compared to CD133-negative cells, CD133-positive cells showed increased proliferation and migration capabilities, and reduced apoptosis, under hypoxic or low-glucose conditions. CD133-positive cells also showed increased expression of GLUT-1 and autophagy activity. Finally, GLUT-1 knockdown or autophagy inhibition reduced the proliferation and migration of CD133-positive laryngeal carcinoma stem cells.

Conclusion: Enhanced glucose uptake and autophagy maintain the tumor behaviors of CD133-positive laryngeal carcinoma stem cells under hypoxic and low-glucose conditions.

Keywords: Laryngeal carcinoma, cancer stem cell, CD133-positive cell, GLUT-1, autophagy

\section{Introduction}

Laryngeal cancer is a common malignant tumor of the head and neck. The 5-year survival rate of laryngeal cancer has not improved in the past 40 years despite the near-continuous development of diagnostic and treatment methods. ${ }^{1}$ The lack of understanding of the mechanisms underlying the functions of laryngeal cancer cells has hampered the development of effective therapeutic strategies.

Compared to ordinary tumor cells, cancer stem cells (CSCs) are typically resistant to apoptosis and therapeutic agents. ${ }^{2,3} \mathrm{CSCs}$ are closely related to the occurrence, development, metastasis, recurrence, and chemoradiotherapy resistance of tumors. ${ }^{4}$ Laryngeal CSCs reportedly express CD133 as a marker. ${ }^{5} \mathrm{CD} 133^{+} \mathrm{CSCs}$ 
have higher tumorigenic and invasive capabilities than CD133- cancer cells. $^{5-10}$ However, the regulation mechanism underlying $\mathrm{CD}_{133^{+}}$CSCs-mediated tumorigenesis remains largely unknown.

Autophagy provides energy for tumor cells from the degradation of proteins and organelles. It can restrain the growth of tumor cells. However, it is also an adaptive response to tumor stressful microenvironments, thereby preventing apoptosis of tumor cells. A basal level of autophagy may promote the survival of cancer cells. ${ }^{11,12}$ However, prolonged and excessive activation of autophagy may induce self-degradation and death of tumor cells. ${ }^{13}$

$\mathrm{CD}_{133^{+}} \mathrm{CSCs}$ show a greater proliferation rate and a lower frequency of apoptosis compared to $\mathrm{CD} 133^{-}$cancer cells in multiple types of tumors, particularly under hypoxic or nutrient-deprived conditions. ${ }^{14,15}$ Interestingly, autophagy induction reportedly promotes the conversion of non-stem-like pancreatic cancer cells into $\mathrm{CD} 133^{+}$ stem-like cells under intermittent hypoxia. ${ }^{16}$ The expression of glucose transporter-1 (GLUT-1) is associated with autophagy activation in CSCs under hypoxic or nutrientdeprived conditions. ${ }^{17-20}$ Autophagy may also affect cellular glucose uptake. ${ }^{21-23}$ Beclin-1, an autophagy marker, plays an important role in the initiation of autophagy. ${ }^{24}$ It promotes the localization of other autophagy-related proteins to autophagosomes, thus promoting the formation and maturation of autophagosomes. High expression of beclin-1 is typically accompanied by enhanced autophagy, increased GLUT-1 expression, and increased glucose uptake in certain types of tumors, such as non-small-cell lung carcinoma and breast cancer. ${ }^{25-27}$ However, a study also reports that beclin-1 and GLUT-1 expression are negatively correlated in 29 cases of head-and-neck squamous cell carcinoma, ${ }^{28}$ indicating that the association between autophagy and glucose metabolism appears heterogeneity among different tumors. In this work, we investigated the regulation role of GLUT-1 and autophagy on the functions of laryngeal carcinoma stem cells under hypoxic or low-glucose conditions, as well as the underlying mechanisms.

\section{Materials and Methods}

\section{Cell Culture and Treatment}

Tu212/Tu686 cells were purchased from the Cell Research Institute of the Chinese Academy of Sciences (Shanghai, China). Tu212 and Tu686 cells were cultured in Roswell Park Memorial Institute-1640 medium (Gibco-BRL,
Gaithersburg, MD), supplemented with $10 \%$ heatinactivated fetal bovine serum (FBS; Hyclone, Logan, UT), $100 \mathrm{U} / \mathrm{mL}$ penicillin, and $100 \mathrm{~g} / \mathrm{mL}$ streptomycin at $37^{\circ} \mathrm{C}$ in an atmosphere containing $5 \% \mathrm{CO}_{2}$.

\section{Sorting and Identification of Laryngeal Carcinoma Cells \\ Magnetic Sorting}

Briefly, $1 \times 10^{7}$ Tu212/Tu686 cells were resuspended in phosphate-buffered saline (PBS). The resuspended cells were added to $100 \mu \mathrm{L}$ FcR Blocking Reagent and $100 \mu \mathrm{L}$ CD133 MicroBeads, mixed, and incubated at $4^{\circ} \mathrm{C}$ for 30 min. Next, $2 \mathrm{~mL}$ PBS was added, and the cells were centrifuged at $300 \times \mathrm{g}$ for $10 \mathrm{~min}$; the supernatant was discarded. Subsequently, the cell pellet was resuspended in 500 $\mu \mathrm{L}$ PBS. The magnetic separation (MS) column was clipped to the magnetic separator and $500 \mu \mathrm{L}$ PBS was added to moisten the column. Next, the cell suspension was added to the MS sorting column. The MS separation column was washed three times with $500 \mu \mathrm{L}$ PBS to remove unbound cells. The column was removed from the magnetic separator, $1 \mathrm{~mL}$ PBS was added, and the cells were expelled from the column using a push rod. After centrifugation at $300 \times \mathrm{g}$ for 10 min, the supernatant was discarded, and the cells were resuspended in $1 \mathrm{~mL}$ PBS and enumerated.

\section{Purification of CDI $33^{+}$Laryngeal Carcinoma Cells} Cells $\left(2 \times 10^{5}\right)$ were removed before and after separation, and centrifuged; the supernatant was discarded. Next, $80 \mu \mathrm{L}$ PBS and $10 \mu \mathrm{L}$ anti-human CD133-PE were added. The sample was gently mixed using a micropipette and incubated at $4^{\circ} \mathrm{C}$ for $10 \mathrm{~min}$. The cells were centrifuged at $1000 \mathrm{rpm}$ for $5 \mathrm{~min}$ and the supernatant was discarded. Precooled PBS $(1 \mathrm{~mL})$ was added, and unbound excess antibody components were removed by two centrifugation and washing steps. After adding 4\% paraformaldehyde and incubation at $4^{\circ} \mathrm{C}$ for $20 \mathrm{~min}$, the supernatant was centrifuged. The cells were transferred to a flow tube and stored at $4{ }^{\circ} \mathrm{C}$ protected from light. Flow cytometry was performed using the standard procedure (Beckman, Fullerton, CA).

\section{Experimental Groups}

Relationship Between the Proliferation and Migration of CDI33+ Cells and the Levels of GLUT-I and

Autophagy Under Hypoxia and Low-Glucose

Conditions

Eight groups were used in this experiment: $\mathrm{CD} 133^{+}(20 \%$ $\left.\mathrm{O}_{2}, 25 \mathrm{mM} \mathrm{Glu}\right)$; CD133- $\left(20 \% \mathrm{O}_{2}, 25 \mathrm{mM} \mathrm{Glu}\right)$; CD133 ${ }^{+}$ 
+hypoxia $\left(1 \% \mathrm{O}_{2}, 25 \mathrm{mM} \mathrm{Glu}\right)$; $\mathrm{CD} 133^{-}+$hypoxia $\left(1 \% \mathrm{O}_{2}\right.$, $25 \mathrm{mM} \mathrm{Glu})$; CD133 $3^{+}$low Glu $\left(20 \% \mathrm{O}_{2}, 2.5 \mathrm{mM} \mathrm{Glu}\right)$; CD133- ${ }^{-}$low Glu $\left(20 \% \mathrm{O}_{2}, 2.5 \mathrm{mM}\right.$ Glu $)$; $\mathrm{CD} 133^{+}$ +hypoxia+low Glu $\left(1 \% \mathrm{O}_{2}, 2.5 \mathrm{mM} \mathrm{Glu}\right)$; and $\mathrm{CD} 133^{-}$ +hypoxia+low Glu $\left(1 \% \mathrm{O}_{2}, 2.5 \mathrm{mM} \mathrm{Glu}\right)$.

Cell Growth, Migration, and Levels of GLUT-I and Autophagy-Related Proteins

Fourteen groups were used in this experiment: $\mathrm{CD} 133^{+}$ +hypoxia+low Glu $\left(1 \% \mathrm{O}_{2}, 2.5 \mathrm{mM} \mathrm{Glu}\right)$; CD133+low Glu ( $\left.1 \% \mathrm{O}_{2}, 2.5 \mathrm{mM} \mathrm{Glu}\right)$; $\mathrm{CD} 133^{+}+$hypoxia+low Glu $\left(1 \% \mathrm{O}_{2}, 2.5 \mathrm{mM} \mathrm{Glu}\right)+\mathrm{NC}$ shRNA; CD133-hypoxia+low Glu (1\% $\mathrm{O}_{2}, 2.5 \mathrm{mM}$ Glu+NC shRNA); CD133 ${ }^{+}+$hypoxia +low Glu $\left(1 \% \mathrm{O}_{2}, 2.5 \mathrm{mM}\right.$ Glu+GLUT-1 shRNA); CD133-+ hypoxia+ low Glu (1\% $\mathrm{O}_{2}, 2.5 \mathrm{mM}$ Glu)+GLUT-1 shRNA); CD133 ${ }^{+}$+hypoxia+low Glu $\left(1 \% \mathrm{O}_{2}, 2.5 \mathrm{mM}\right.$ Glu+beclin-1 shRNA); CD133-'hypoxia+low Glu $\left(1 \% \mathrm{O}_{2}, 2.5 \mathrm{mM}\right.$ Glu +beclin-1 shRNA); CD133 ${ }^{+}+$hypoxia+low Glu $\left(1 \% \mathrm{O}_{2}, 2.5\right.$ mM Glu+3-MA); $\mathrm{CD} 133^{-}$-hypoxia+low Glu $\left(1 \% \mathrm{O}_{2}, 2.5 \mathrm{mM}\right.$ Glu+3-MA); CD133 ${ }^{+}$+hypoxia+low Glu $\left(1 \% \mathrm{O}_{2}, 2.5 \mathrm{mM} \mathrm{Glu}\right.$ +CQ); CD133- ${ }^{-}$hypoxia+low Glu ( $\left.1 \% \mathrm{O}_{2}, 2.5 \mathrm{mM} \mathrm{Glu}+\mathrm{CQ}\right)$; CD133 ${ }^{+}$-hypoxia+low Glu $\left(1 \% \mathrm{O}_{2}, 2.5 \mathrm{mM} \mathrm{Glu}\right)+$ rapamycin); and CD133-hypoxia+low Glu ( $\left.1 \% \mathrm{O}_{2}, 2.5 \mathrm{mM} \mathrm{Glu}\right)$ +rapamycin).

\section{Clonogenic Assay}

The cell suspension was dispersed; the percentage of individual cells was greater than $95 \%$. Next, cells were counted, and the cell density was adjusted to $250 / \mathrm{mL}$ by adding culture medium. The cell suspension was added to a 6 -well plate $(2 \mathrm{~mL}$ per well) with a gentle shake. The plate was placed in an incubator for 2 to 3 weeks, and the medium was replaced every 3 days. The culture was terminated when clones became visible. The medium was discarded, and the cells were gently washed twice with PBS, stained with $1 \%$ crystal violet at room temperature for $1 \mathrm{~h}$, and photographed.

\section{Cell-Counting Kit-8 Assay}

Cells were incubated at $37^{\circ} \mathrm{C}$ in an atmosphere containing $5 \% \mathrm{CO}_{2}$ for $48 \mathrm{~h}$. Next, $20 \mu \mathrm{L}$ Cell Counting Kit-8 (CCK8 ) solution was added, and the cells were incubated in the dark for $1 \mathrm{~h}$. The absorption at $450 \mathrm{~nm}$ of the suspension was measured using a Spectra Plus Microplate Reader (Molecular Devices, Sunnyvale, CA).

\section{Flow Cytometry}

Briefly, 10× Binding Buffer was diluted 1:10 with deionized water. Cells were digested using trypsin, collected by centrifugation for $5 \mathrm{~min}$, and resuspended in $500 \mu \mathrm{L}$ Annexin V binding buffer. Next, $5 \mu \mathrm{L}$ fluorescein isothiocyanate and $10 \mu \mathrm{L}$ propidium iodide (Sigma Aldrich Co., St. Louis, MO) were added and incubated for $10 \mathrm{~min}$ in darkness at RT. Finally, the proportions of non-apoptotic and apoptotic cells were determined in triplicate by flow cytometry with ModFit LT software (Becton Dickinson, Mountain View, CA)

\section{Transwell Assay}

Cells were digested with trypsin and the culture medium was discarded. Next, the cells were washed once or twice with PBS and resuspended in serum-free medium (containing $0.2 \%$ bovine serum albumin) to a density of $1 \times 10^{6} / \mathrm{mL}$. Cell suspension $(200 \mu \mathrm{L})$ was added to the upper Transwell chamber and $600 \mu \mathrm{L}$ medium containing $10 \%$ FBS was added to the lower chamber. The cells were incubated in a $5 \% \mathrm{CO}_{2}$ atmosphere at $37^{\circ} \mathrm{C}$ for 24 h. The Transwell chamber was removed, and the culture medium was discarded. Then the chamber was washed twice with calcium-free PBS, fixed in formaldehyde for 30 min, air-dried, and the cells were stained with $0.1 \%$ crystal violet for $20 \mathrm{~min}$. Finally, the upper layer of unmigrated cells was gently removed using cotton swabs and washed three times with PBS.

\section{Quantitative Real-Time Polymerase Chain Reaction}

The cells were collected, washed three times with precooled PBS, centrifuged at $1500 \mathrm{rpm}$ for $3 \mathrm{~min}$, and lysed on ice in the presence of TRIzol. Total RNA was extracted from the cells according to the manufacturer's instructions. Briefly, $1 \mu \mathrm{g}$ RNA was reverse-transcribed using a First-Strand cDNA Synthesis Kit (K1622; Fermentas, Burlington, ON, Canada) and amplified by PCR using a SYBR Green qPCR Kit (Merck, Darmstadt, Germany). The PCR program was $37^{\circ} \mathrm{C}$ for $60 \mathrm{~min}, 85^{\circ} \mathrm{C}$ for $5 \mathrm{~min}$, and $4^{\circ} \mathrm{C}$ for $5 \mathrm{~min}$. The amplification products were stored at $-20^{\circ} \mathrm{C}$. The primers for GLUT-1, Beclin-1, Atg7, Atg5, and LC3 were designed and synthesized by Sangon Biotech (Table 1). The $2^{\Delta \Delta C t}$ method was used to calculate relative gene expression levels.

\section{Western Blotting}

Total proteins were extracted from cells and tumor tissues in radioimmunoprecipitation assay buffer. The cells were 
Table I Primer Sequence $\left(5^{\prime}-3^{\prime}\right)$

\begin{tabular}{|c|c|}
\hline \multicolumn{2}{|l|}{ GLUT-I } \\
\hline Forward Primer & GGCCAAGAGTGTGCTAAAGAA \\
\hline Reverse Primer & ACAGCGTTGATGCCAGACAG \\
\hline \multicolumn{2}{|l|}{ Beclin-I } \\
\hline Forward Primer & CCATGCAGGTGAGCTTCGT \\
\hline Reverse Primer & GAATCTGCGAGAGACACCATC \\
\hline \multicolumn{2}{|l|}{ Atg7 } \\
\hline Forward Primer & CTGCCAGCTCGCTTAACATTG \\
\hline Reverse Primer & CTTGTTGAGGAGTACAGGGTTTT \\
\hline \multicolumn{2}{|l|}{ Atg5 } \\
\hline Forward Primer & AAAGATGTGCTTCGAGATGTGT \\
\hline Reverse Primer & CACTTTGTCAGTTACCAACGTCA \\
\hline \multicolumn{2}{|l|}{ LC3 } \\
\hline Forward Primer & AACATGAGCGAGTTGGTCAAG \\
\hline Reverse Primer & GCTCGTAGATGTCCGCGAT \\
\hline \multicolumn{2}{|l|}{ GAPDH } \\
\hline Forward Primer & GGAGCGAGATCCCTCCAAAAT \\
\hline Reverse Primer & GGCTGTTGTCATACTTCTCATGG \\
\hline
\end{tabular}

collected, washed three times with precooled PBS, and centrifuged at $1500 \mathrm{rpm}$ for $3 \mathrm{~min}$. An appropriate volume of cell lysate was added, and the cells were lysed on ice for 30 min. The supernatant was centrifuged at $1200 \mathrm{rpm}$ at $4^{\circ} \mathrm{C}$ for $30 \mathrm{~min}$ and stored at $-80^{\circ} \mathrm{C}$. After assaying the protein concentration, samples were added to $4 \times$ sodium dodecyl sulfate loading buffer, boiled for 5 to $10 \mathrm{~min}$, and centrifuged at $12,000 \times \mathrm{g}$ for $1 \mathrm{~min}$. Proteins $(30 \mu \mathrm{g})$ were subjected to SDS-polyacrylamide gel electrophoresis (SDS-PAGE) and transferred to a polyvinylidene difluoride membrane (Millipore). Primary antibodies against GLUT-1 (Abcam), beclin-1, LC3 (Proteintech), Atg7, Atg5, HIF-1 $\alpha$ and $\beta$-actin (Abcam) were added and incubated at $4^{\circ} \mathrm{C}$ overnight; $\beta$-actin served as the internal control. After washing three times with Tris-buffered saline/Tween 20, the secondary antibodies were added for $1 \mathrm{~h}$ at room temperature. The blots were developed using an enhanced chemiluminescence assay kit (Beyotime Biotech) and analyzed semi-quantitatively using the ChemiDoc XRS+ System (Bio-Rad).

\section{Transmission Electron Microscopy}

Cells were collected, washed in PBS, fixed in $2.5 \%$ glutaraldehyde, post-fixed in $1 \%$ osmium tetroxide, and dehydrated in ethanol and acetone. After embedding in epoxy resin, sections were cut and stained with uranyl acetate and lead citrate. Autophagy was visualized by transmission electron microscopy (TEM; Thermo Fisher Scientific, Waltham, MA).

\section{Statistical Analysis}

All experiments were performed independently thrice at least. Migrated cell numbers and the colone number were calculated by using Image $\mathrm{J}$ software and analysed by GraphPad Prism 8.0. The difference among different groups were analyzed using GraphPad Prism 8.0 (CA, USA) using one-way analysis of variance. $\mathrm{p}<0.05$ was considered as statistical significance.

\section{Results}

\section{Proliferation, Migration, and Apoptosis of CDI $33^{+}$Stem Cells}

To investigate the role of GLUT-1 in LCSCs, we first sorted $\mathrm{CD}_{133^{+}}$Tu212 cells. Flow cytometry results showed that the proportion of $\mathrm{CD}_{133^{+}} \mathrm{Tu} 212$ cells was $\sim 8 \%$ before sorting and surpassed $90 \%$ after sorting. In addition, the $\mathrm{CD}_{133}{ }^{+} \mathrm{Tu} 212$ cells showed good viability (Figure 1A).

Next, we investigated the growth, proliferation, apoptosis, and migration of $\mathrm{CD}_{133^{+}} \mathrm{Tu} 212$ cells. The clonal number of Tu212 $\mathrm{CD}_{133^{+}}$cells was significantly greater than that of $\mathrm{Tu} 212 \mathrm{CD} 133^{-}$cells under hypoxic $\left(1 \% \mathrm{O}_{2}\right)$, lowglucose (2.5 mM glucose), and hypoxic+low-glucose conditions. However, the clonal number of $\mathrm{CD}_{133^{+}}$was higher than that in CD133- Tu212 cells under normal culture conditions (Figure 1B). Moreover, compared to CD133- cells, the cell viability of CD133 ${ }^{+} \mathrm{Tu} 212$ cells was significantly increased under hypoxic, low-glucose, and hypoxic+lowglucose conditions (Figure 1C). Flow cytometry results showed that the apoptotic rate of $\mathrm{CD}_{133^{+}} \mathrm{Tu} 212$ cells was significantly lower than that of CD133- $\mathrm{Tu} 212$ cells under hypoxic, low-glucose, and hypoxic+low-glucose conditions (Figure 1D). In a Transwell assay, the migration capability of $\mathrm{CD}_{133^{+}} \mathrm{Tu} 212$ cells was greater than that of CD133Tu212 cells under all three stress conditions (Figure 1E). By contrast, cell viability, apoptosis and migration were comparable between $\mathrm{CD}_{133^{+}}$Tu212 cells and CD133- cells under normal culture conditions, with $\mathrm{CD} 133^{+}$cells showing only a slight increase in clonal number. Hence, CD133 ${ }^{+}$ 

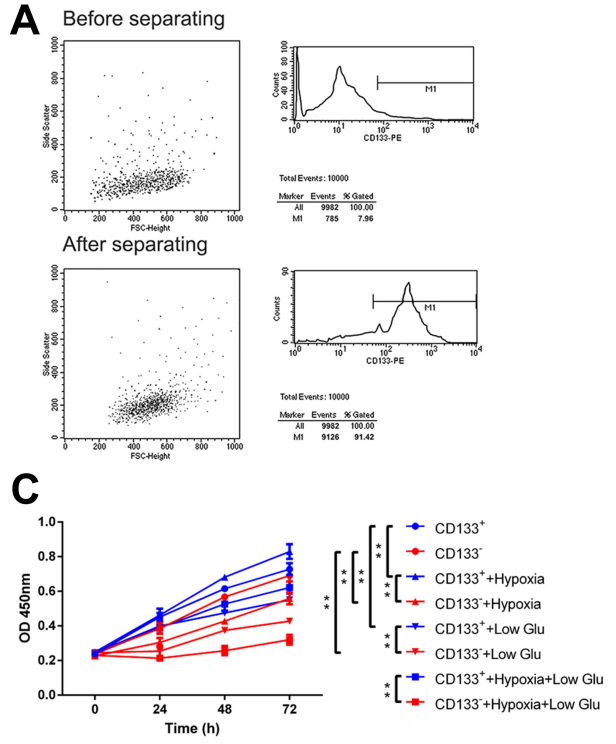

B

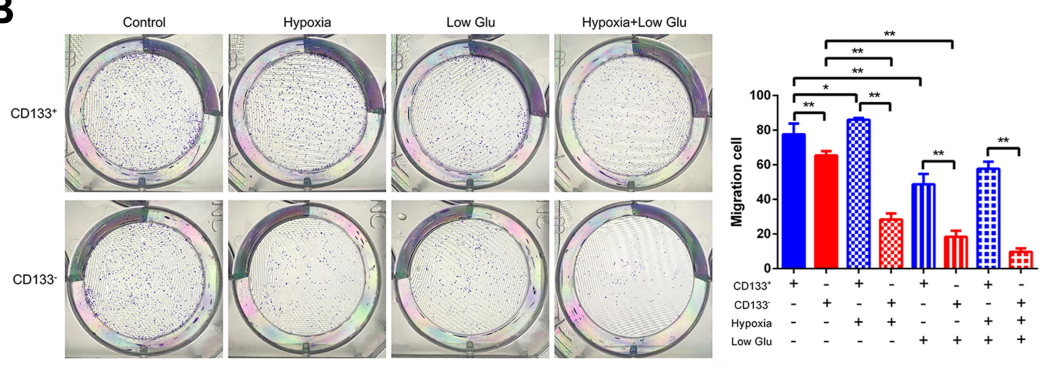

D

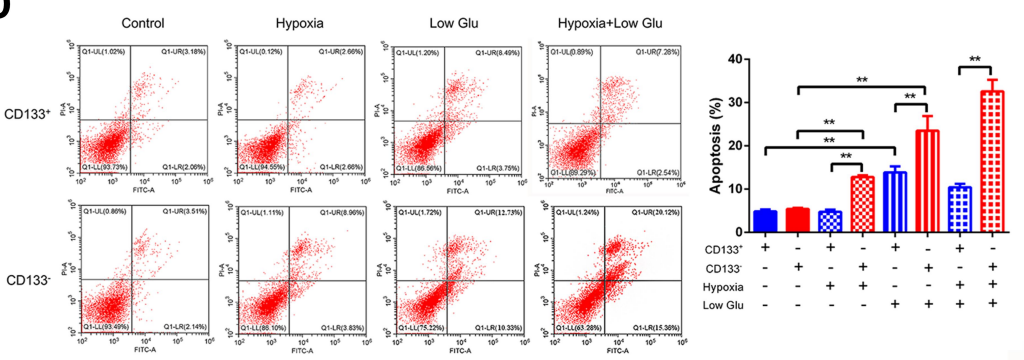

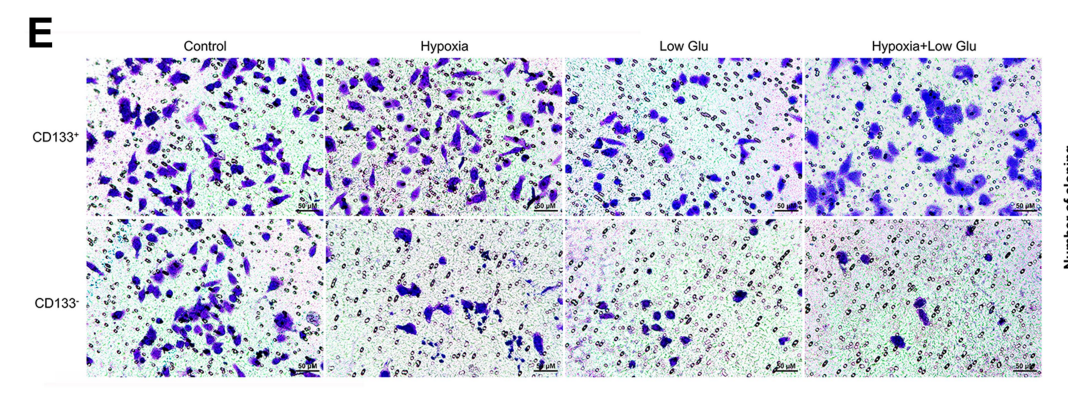

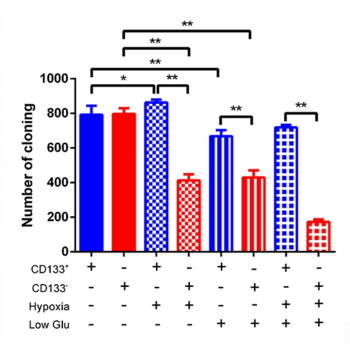

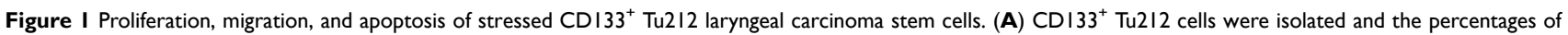
$\mathrm{CDI} 33^{+}$cells before and after purification were determined by flow cytometry. (B-E) Tu2I2 cells were subjected to hypoxia or low glucose, singly or in combination. Proliferation as evaluated using a colony-formation assay (B) and a CCK-8 assay (C). (D) Apoptosis as assessed by Annexin V-PI staining and flow cytometry. (E) Cell migration as determined using a Transwell assay. Data are means \pm SDs and are representative of at least three independent experiments. $* P<0.05$; $* * P<0.0$ I; two-tailed unpaired Student's $t$-test.

laryngeal carcinoma stem cells showed greater proliferation and migration capabilities than $\mathrm{CD} 133^{-}$cells in the presence of stressors.

\section{GLUT-I Expression and Autophagy Activity of $\mathrm{CDI} 33^{+}$Laryngeal Carcinoma Stem Cells}

GLUT-1 overexpression promotes the proliferation, invasion, and metastasis of cancer cells, particularly under hypoxia and starvation conditions. ${ }^{6,7}$ Activation of autophagy promotes the functions of $\mathrm{CD}_{133^{+}}$cells under hypoxia, ${ }^{15,16}$ likely by enhancing glucose uptake. ${ }^{21-23}$ Therefore, we explored whether the increased proliferation and migration of $\mathrm{CD} 133^{+} \mathrm{Tu} 212$ cells were associated with elevated GLUT-1 expression and autophagy. To this end, we investigated the expression of GLUT-1 and autophagy-related molecules in Tu212 cells under hypoxic and low-glucose conditions. The GLUT-1 mRNA level in $\mathrm{CD}_{133^{+}} \mathrm{Tu} 212$ cells was significantly higher than that in CD133- Tu212 cells under normal, hypoxic, low-glucose, and hypoxic + low-glucose conditions. The GLUT-1 mRNA level of $\mathrm{CD}_{133^{+}} \mathrm{Tu} 212$ cells under hypoxic, low-glucose, and hypoxic+low-glucose conditions was higher than that under normal culture conditions (Figure 2A). Western blotting showed that the GLUT-1 protein level in $\mathrm{CD}_{133^{+}}$Tu212 cells was significantly higher than that in CD133- Tu212 cells irrespective of the culture conditions (Figures 2B and 3). Additionally, HIF-1 $\alpha$ expression was significantly higher in the CD133-positive cells than that in the CD133-negative cells (Figures 2B and 3). It is confirmed that GLUT1 transcription and expression can be regulated by HIF-1 $\alpha$. Thus, the higher level of GLUT1 in CD133-positive cells might be attributed to the higher 
A
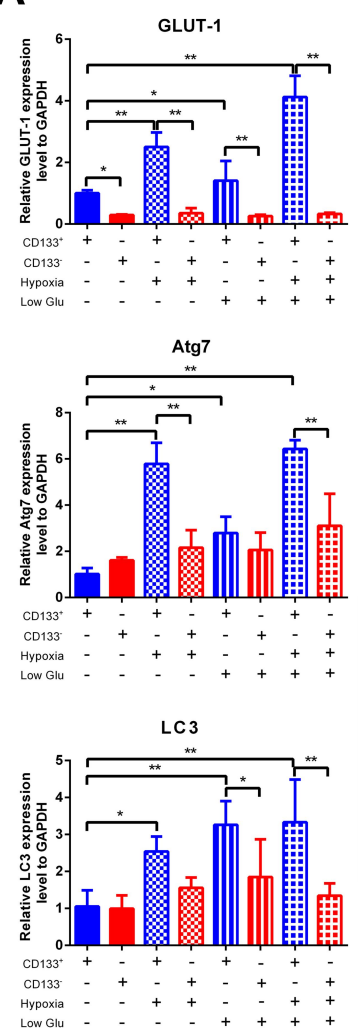

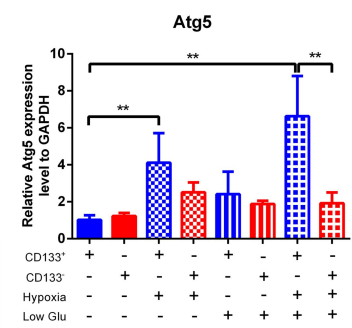

C

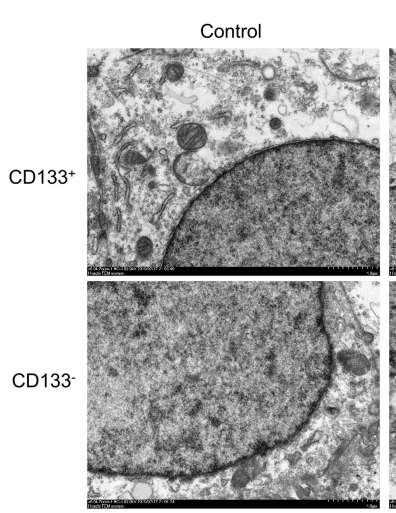

B

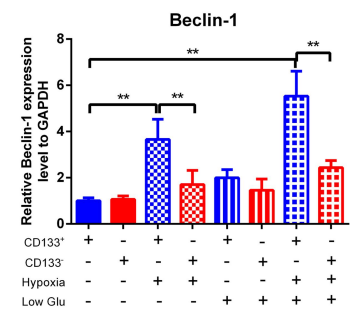

$$
\begin{array}{lllllllll}
\mathrm{CD}_{133} & + & - & + & - & + & - & + & - \\
\text { CD133 } & - & + & - & + & - & + & - & + \\
\text { Hypoxia } & - & - & + & + & - & - & + & + \\
\text { Low Glu } & - & - & - & - & + & + & + & +
\end{array}
$$
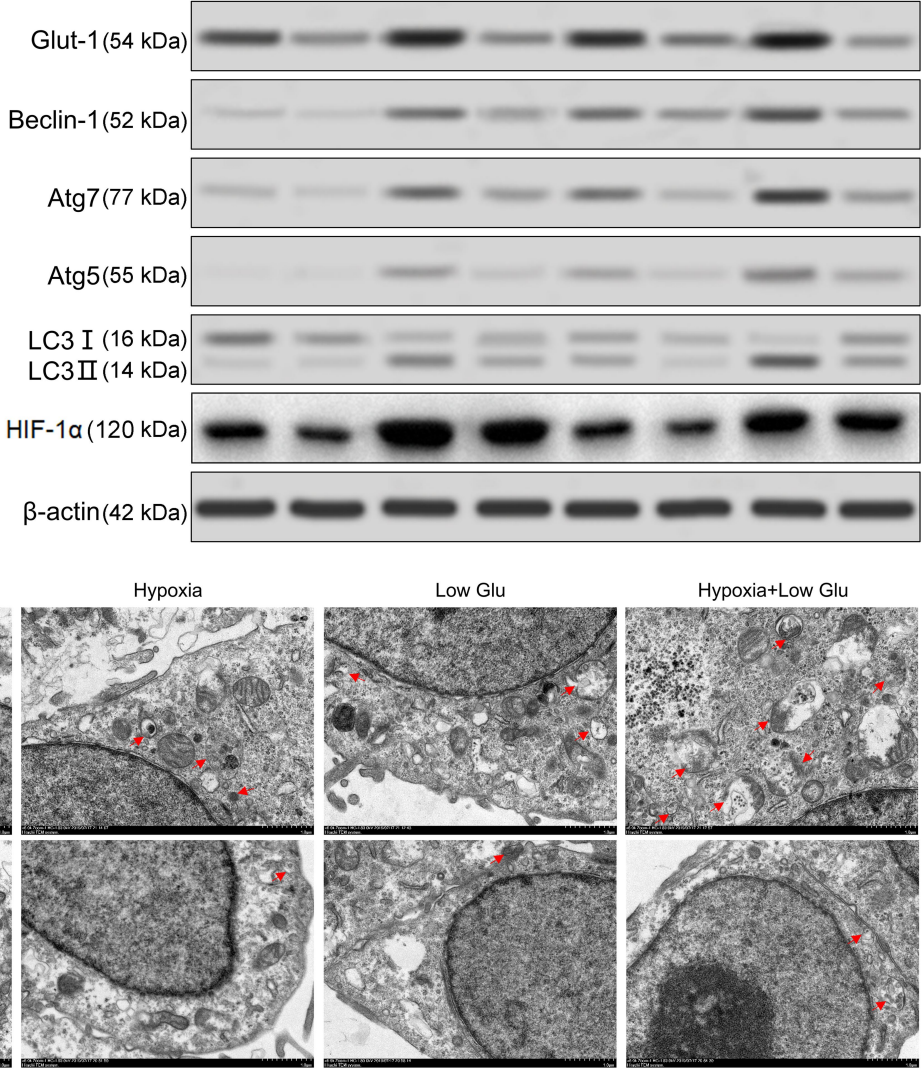

Figure 2 GLUT-I and autophagy marker expression in stressed CDI33+ Tu2I2 laryngeal carcinoma stem cells. Tu2 2 cells were challenged with hypoxia or low glucose, singly or in combination. (A) mRNA levels of GLUT-I, beclin- I, Atg7, Atg5, and LC3 as evaluated by qRT-PCR. (B) Protein levels of GLUT-I, beclin-I, Atg7, Atg5, LC3II/I and HIF-I $\alpha$ as measured by Western blotting. (C) Autophagy as examined by TEM. Data are means \pm SDs and are representative of at least three independent experiments. $* P<$ $0.05 ; * * p<0.01$; two-tailed unpaired Student's $t$-test.

expression of HIF- $1 \alpha$. It is also proved that hypoxia promotes the accumulation of HIF-1 $\alpha$. In the present study, HIF-1 $\alpha$ expression was notably elevated in both the hypoxia or hypoxia plus low glucose conditions (Figures 2B and 3). Particularly, in CD133-positive cells, hypoxia or hypoxia plus low glucose conditions also promoted the expression of GLUT1, which was significantly higher than that in the normal oxygen group (Figures 2A,B and 3), suggesting that the increase of GLUT1 expression in CD133-positive cells under hypoxic or hypoxic plus low glucose conditions might also be related to the increase of HIF- $1 \alpha$ content.
Hypoxic or low-glucose conditions increased the expression of Beclin-1, Atg7, Atg5, and LC3 in CD133 Tu212 cells, and to a lesser degree in CD133- Tu212 cells. Compared to CD133- Tu212 cells, the levels of these autophagy markers were significantly higher in $\mathrm{CD} 133^{+}$ Tu212 cells under hypoxic, low-glucose, and hypoxic +low-glucose conditions (Figures 2A, B, Figure 3). TEM results showed that the number of autophagosomes in $\mathrm{CD}_{133^{+}}$Tu212 cells was significantly greater than that in CD133- Tu212 cells under the above three conditions, indicating enhanced autophagy (Figure 2C). Thus, the increased survival and migration of laryngeal carcinoma 

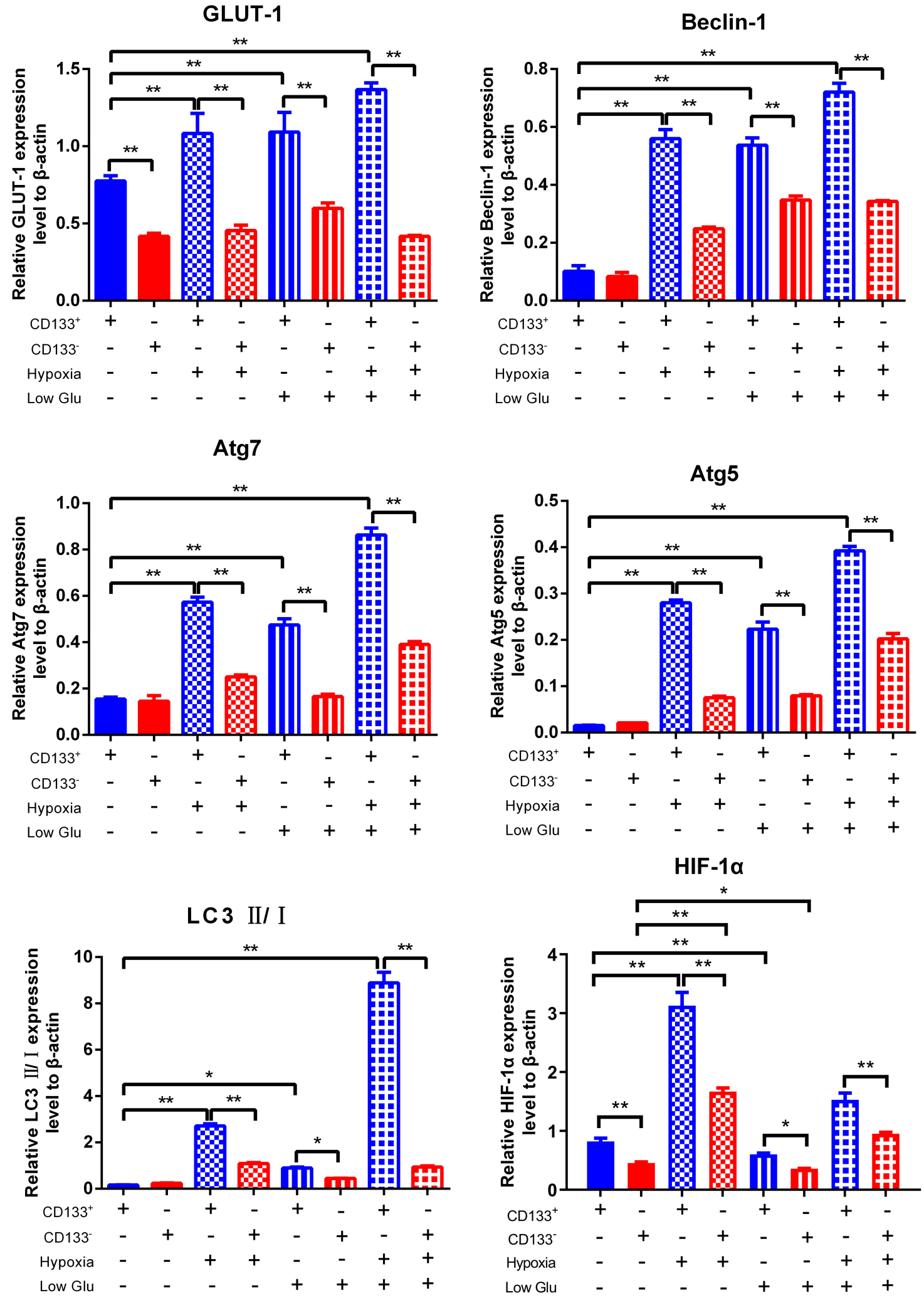

Figure 3 Relative quantitative analysis of protein expression in Figure 2B. B-actin was served as the internal control. Data were mean \pm SD and were representative of at least 3 independent experiments. $* P<0.05 ; * * P<0.01$. 
stem cells under hypoxic and low-glucose conditions may be associated with high GLUT-1 expression and autophagy.

\section{Association Between GLUT-I Expression and Autophagy Markers in $\mathrm{CD} 133^{+}$ Laryngeal Carcinoma Stem Cells}

Next, GLUT-1 and beclin-1 expression were silenced using shRNAs, and autophagy signaling pathway was inhibited by using 3-MA and chloroquine, and activated by using rapamycin in $\mathrm{CD} 133^{+}$Tu212 cells. qRT-PCR and Western blotting results showed that the mRNA and protein levels of GLUT-1, beclin-1, Atg7, and Atg5, and the LC3II/LC3I ratio in CD133 ${ }^{+}$Tu212 cells were higher than those in CD133- $\mathrm{Tu} 212$ cells under hypoxic+low-glucose conditions. After transfection with the GLUT-1 shRNA, the Beclin-1, Atg7, and Atg5 mRNA levels and the LC3II/ LC3I ratio in Tu212 $\mathrm{CD}_{133^{+}}$cells were significantly decreased. After transfection with the beclin-1 shRNA, the LC3II/LC3I ratio in CD133 ${ }^{+}$Tu212 cells was significantly decreased, but the expression of GLUT-1, ATG7, and ATG5 was unaffected. The exposure of autophagy inhibitor 3-MA significantly decreased the levels of beclin-1, Atg7, and Atg5, and the LC3II/LC3I ratio in $\mathrm{CD}_{133^{+}}$Tu212 cells, whereas did not affect GLUT-1 expression. By contrast, CQ did not affect the expression of GLUT-1, beclin-1, Atg7, and Atg5 or the LC3II/LC3I ratio in $\mathrm{CD}_{133^{+}} \mathrm{Tu} 212$ cells. Rapamycin significantly increased the expression of beclin-1 and the LC3II/LC3I ratio in $\mathrm{CD}_{133^{+}} \mathrm{Tu} 212$ cells (Figures $4 \mathrm{~A}, \mathrm{~B}$ and 5). Therefore, the expression of GLUT-1 and autophagy markers is closely associated in stressed laryngeal carcinoma stem cells. TEM analysis showed that silencing of GLUT1 and beclin-1, or inhibition of autophagy, significantly decreased the number of autophagosomes in $\mathrm{CD} 133^{+}$ Tu212 cell under hypoxic+low-glucose conditions. By contrast, activation of autophagy by rapamycin significantly increased the number of autophagosomes in $\mathrm{CD}_{133^{+}}$Tu212 cells (Figure 4C). Subsequently, we also found that low glucose or autophagy inducers inhibited the expression of HIF-1 $\alpha$, while autophagy inhibitors increased HIF-1 $\alpha$ expression in CD133-positive cells (Figures 4B and 5). Previous evidence indicate that
A
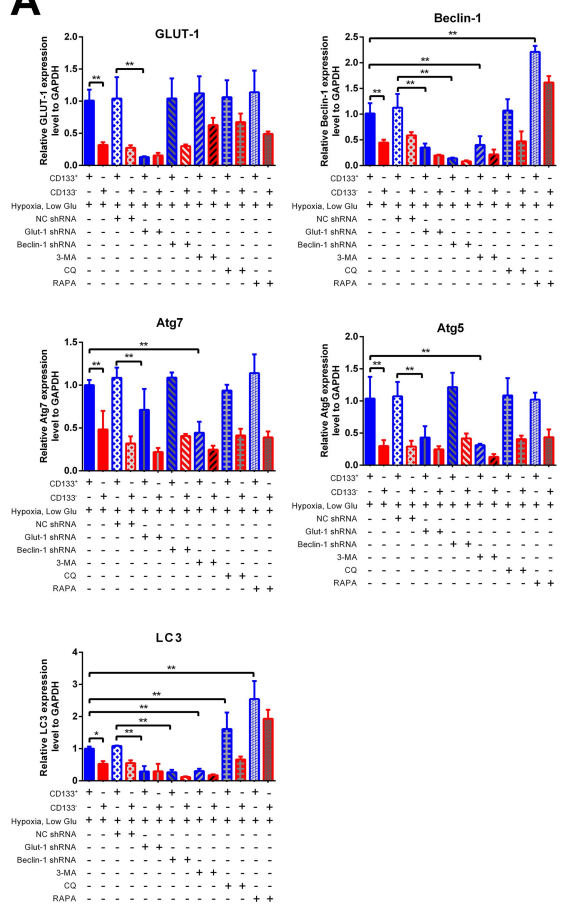

B
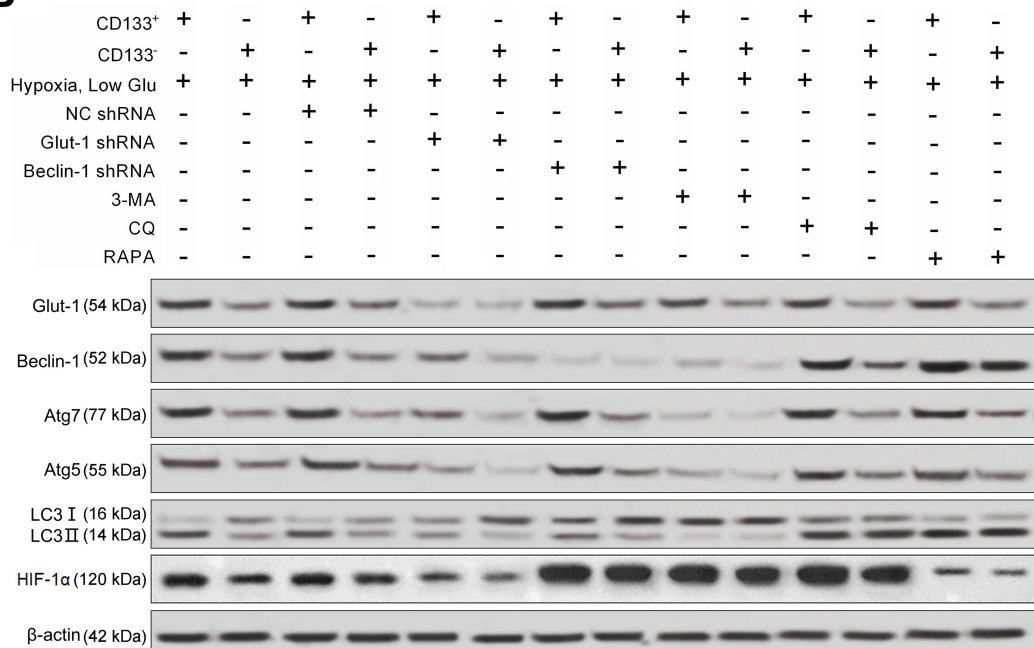

C

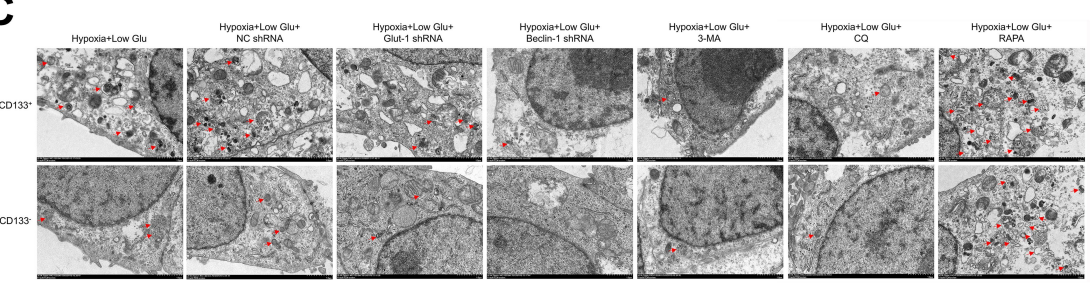

Figure 4 Relationship between GLUT-I expression and autophagy in stressed CD $133^{+}$Tu2 I 2 laryngeal carcinoma stem cells. Tu2 I 2 cells were transfected with GLUT-I shRNA or beclin-I shRNA or treated with an autophagy inhibitor (3-MA, CQ) or activator (rapamycin). Then the cells were challenged with hypoxia plus low glucose. (A) mRNA levels of GLUT-I, beclin-I, Atg7, Atg5, and LC3 as evaluated by qRT-PCR. (B) Protein levels of GLUT-I, beclin-I, Atg7, Atg5, LC3II/I and HIF-I $\alpha$ as measured by Western blotting. (C) Autophagy as examined by TEM. Data are means \pm SDs and are representative of at least three independent experiments. *P $<0.05$; **P $<0.0$ I; twotailed unpaired Student's $t$-test. 

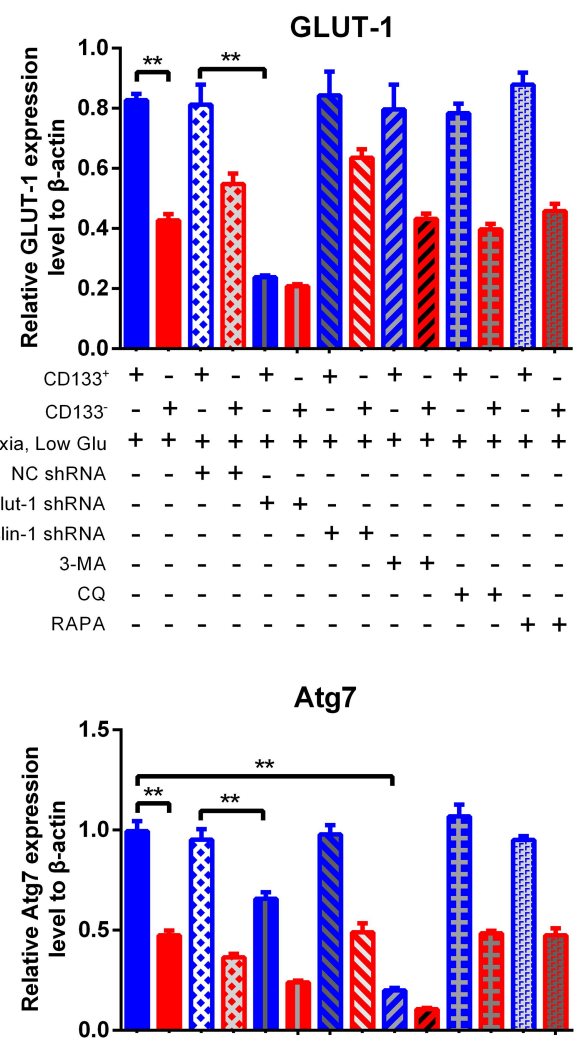

$\mathrm{CD}_{133^{+}}+-+$+ -+ + -+ + $\mathrm{CD}_{133}-+$ - + - -+ - + - + - +

Hypoxia, Low Glu ++++++++++++ NC ShRNA - $-++\ldots$ Glut-1 shRNA - $-{ }_{-}++-{ }_{-}-{ }_{-}-{ }_{-}$ Beclin-1 shRNA - $-\quad-\quad-++-\quad-\quad-$ 3-MA - $-\quad-\quad-\quad-\quad++-\quad-$

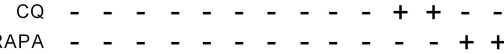

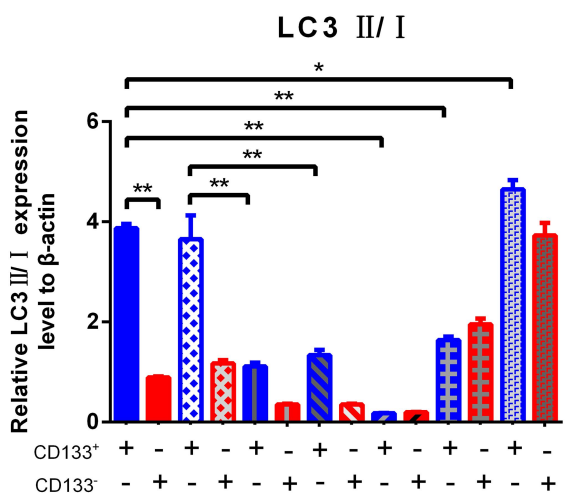
Hypoxia, Low Glu ++++++++++++ NC shRNA - $-++-c_{-}-{ }_{-}-{ }_{-}$ Glut-1 shRNA - - - + + - - - - - Beclin-1 shRNA - - - - - $+++-c_{-}-$ 3-MA - ----++-$\mathrm{CQ}--\quad-\quad--\frac{-}{-}+-$
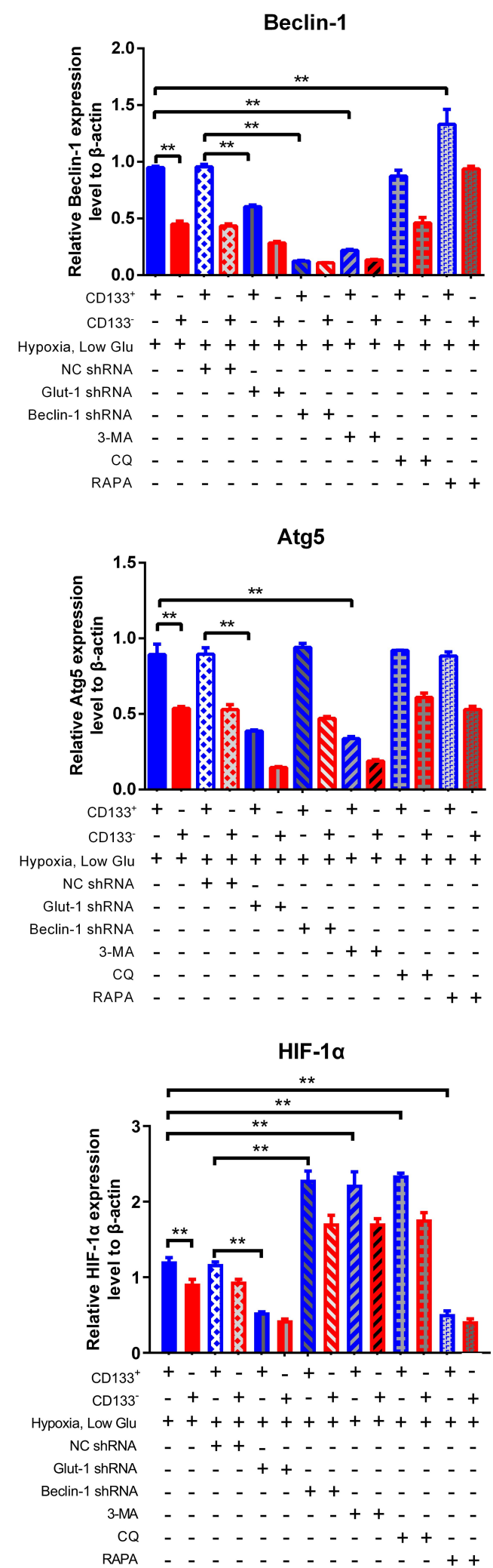

Figure 5 Relative quantitative analysis of protein expression in Figure 4B. $\beta$-actin was served as the internal control. Data were mean \pm SD and were representative of at least 3 independent experiments. $* P<0.05 ; * * P<0.01$. 
autophagy promotes the degradation of HIF-1 $\alpha .^{29}$ Herein, low glucose activated autophagy of CD133-positive cells. Thus, low glucose-mediated the decline of HIF-1 $\alpha$ implicated in the activation of autophagy process in CD133positive cells.

\section{GLUT-I Knockdown and Autophagy Inhibition Reduce the Proliferation and Migration of CDI $33^{+}$Laryngeal Carcinoma Stem Cells}

In the functional analysis, we found that silencing of GLUT1 markedly decreased the clonal-forming capacity, cell proliferation, and migration capability of $\mathrm{CD}_{133^{+}} \mathrm{Tu} 212$ cells under oxygen- and glucose-deprived condition (Figure 6AC). In contrast, the apoptotic rate of $\mathrm{CD} 133^{+} \mathrm{Tu} 212$ cells was significantly increased by the silencing of GLUT-1 (Figure 6D). Similarly, Beclin-1 silencing or autophagy inhibitor (3-MA, CQ) treatment also significantly decreased the above malignant behaviors of $\mathrm{CD}_{133^{+}} \mathrm{Tu} 212$ cells. Importantly, upon GLUT-1 silence or autophagy inhibition, the survival and migratory advantages of $\mathrm{CD}_{133^{+}} \mathrm{Tu} 212$ cells over CD133- Tu212 counterparts were greatly compromised. To our surprise, autophagy activator Rapamycin also reduced the malignant behaviors of $\mathrm{CD}_{133^{+}} \mathrm{Tu} 212$ cells, suggesting that the excessive autophagy may be harmful for stem cells as well (Figure 6A-D). Taken together, the enhanced glucose uptake and autophagy are responsible for maintaining the growth and migration of the stressed laryngeal carcinoma stem cells.

Additionally, another laryngeal cancer cell line Tu686 was employed to confirm the role of GLUT1 and autophagy in the progression of laryngeal cancer under hypoxia or hypoxia plus low glucose conditions. The results showed that GLUT1 expression, cell viability, migration capability and autophagy intensity significantly elevated in CD133positive Tu686 cells, which were higher than that in CD133negative Tu686 cells under hypoxia or hypoxia plus low glucose conditions. However, either GLUT1 inhibition or Beclin-1 inhibition significantly reduced the autophagy level, cell viability and migration capability of CD133positive TU686 cells (Figure 7A-D). These results indicate that GLUT1 and autophagy play important roles in laryngeal cancer progression under hypoxia and hypoglycemia treatment. The data indicate that GLUT1 and autophagy plays the determinant role in the progression of laryngeal cancer.

\section{Discussion}

Glucose is the main energy source for tumor cells. As a key transporter of extracellular glucose..$^{6,7,30}$ GLUT-1 is
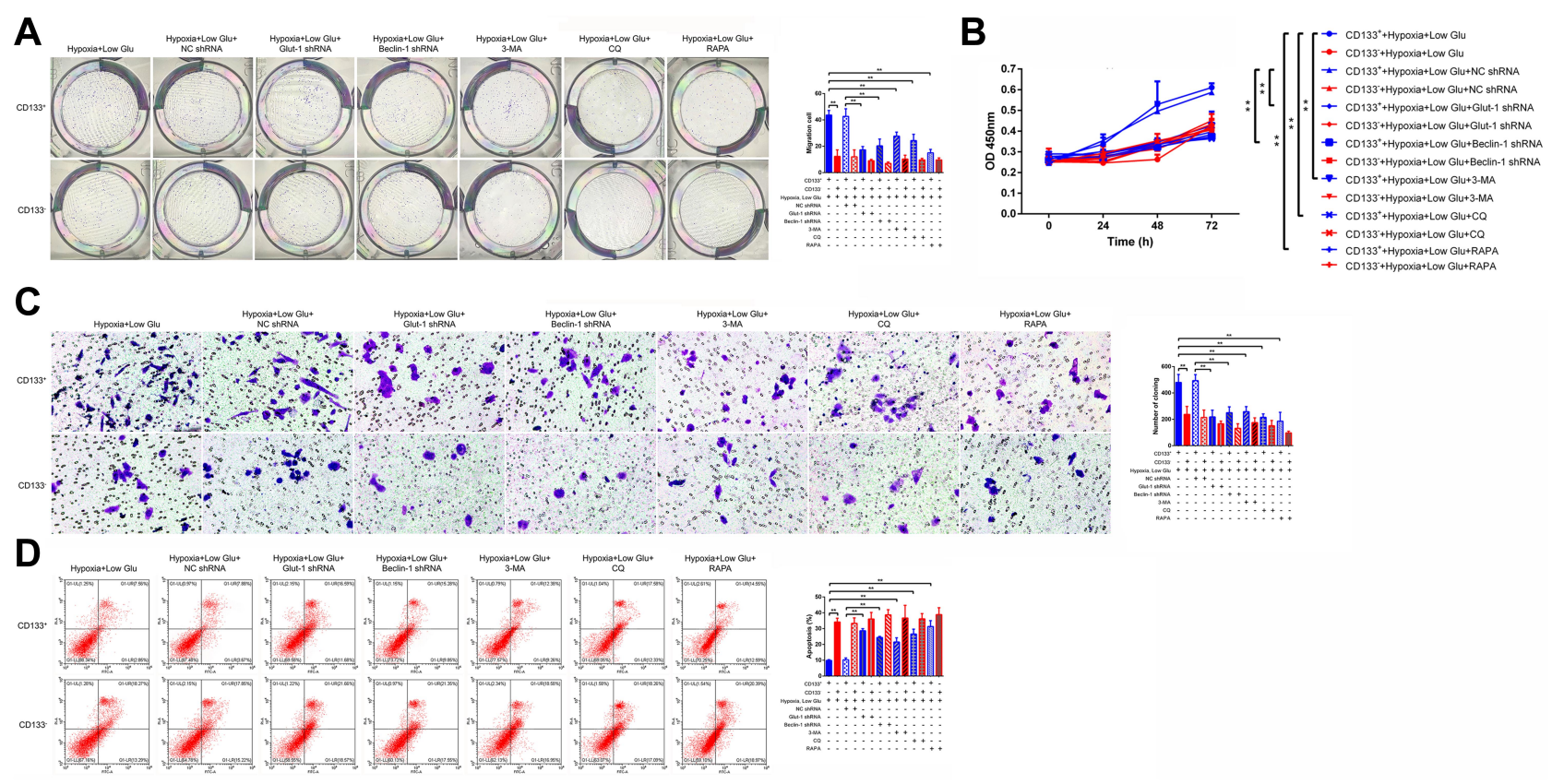

Figure 6 Effects of GLUT-I knockdown or autophagy modulation on the malignant behaviors of stressed CDI $33^{+}$Tu2 12 laryngeal carcinoma stem cells. Tu2 12 cells were transfected with GLUT-I shRNA or beclin-I shRNA or treated with an autophagy inhibitor (3-MA, CQ) or activator (rapamycin). Then the cells were subjected to hypoxia plus low glucose. (A, B) Proliferation as evaluated using a colony-formation assay (A) and a CCK-8 assay (B). (C) Cell migration as determined using a Transwell assay. (D) Apoptosis as evaluated by Annexin V-PI staining with flow cytometry. Data are means \pm SDs and are representative of at least three independent experiments. $* P<0.05$; **P $<0.01$; two-tailed unpaired Student's $t$-test. 

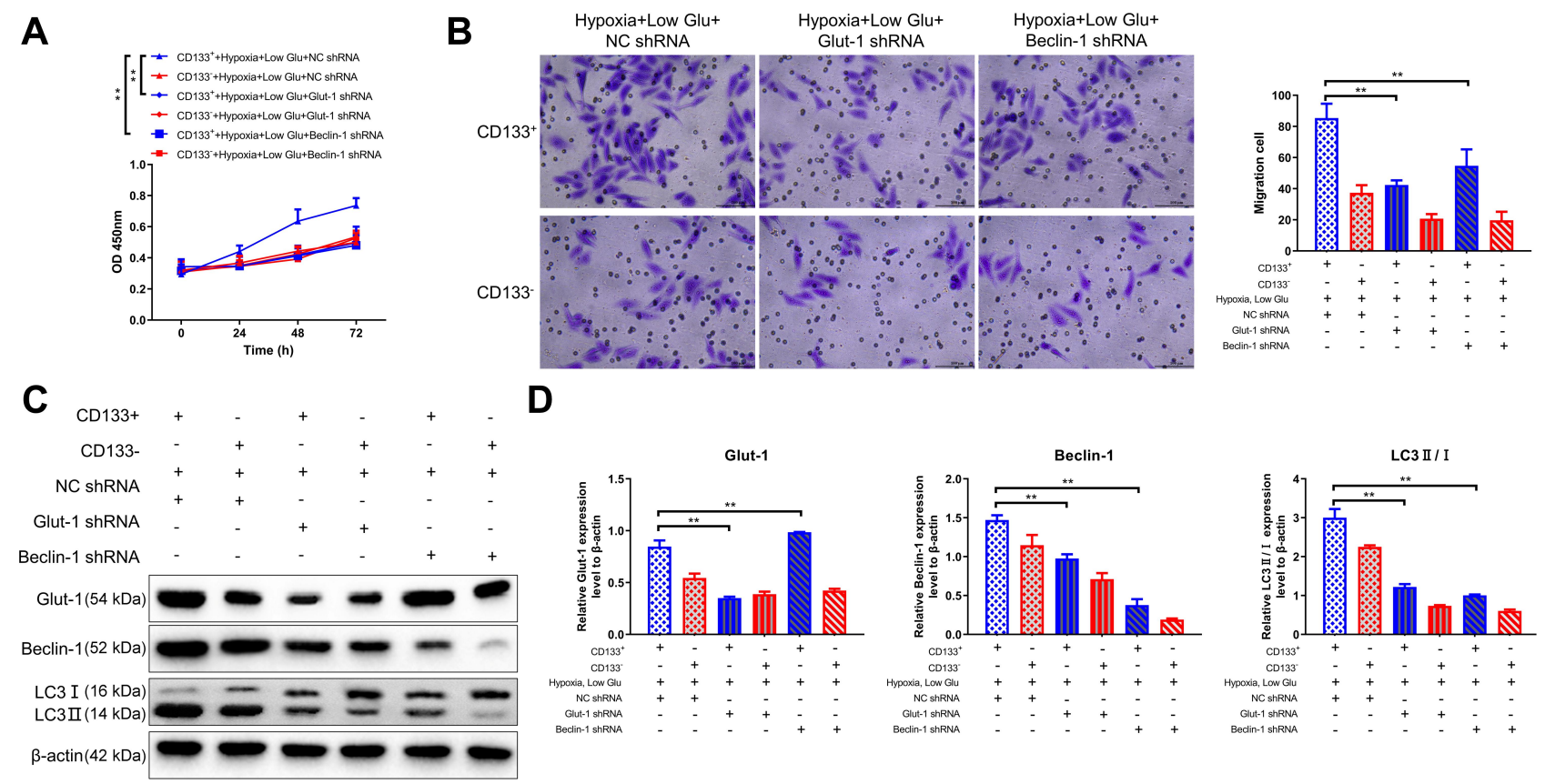

D
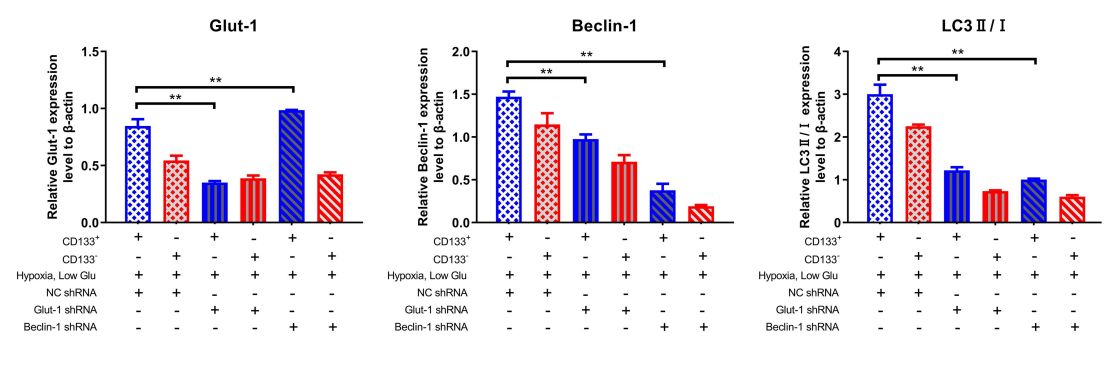

Figure 7 Effects of GLUT-I or Beclin-I knockdown on the malignant behaviors of stressed CDI33 ${ }^{+}$Tu686 laryngeal carcinoma stem cells. Tu686 cells were transfected with GLUT-I shRNA or beclin-I shRNA. Then the cells were subjected to hypoxia plus low glucose. (A) Proliferation as evaluated using a CCK-8 assay. (B) Cell migration as determined using a Transwell assay. (C) Protein levels of GLUT-I, beclin-I and LC3IIII as measured by Western blotting. (D) Relative quantitative analysis of protein expression in (C). Data are means \pm SDs and are representative of at least three independent experiments. ${ }^{*} P<0.05 ; * * P<0.01$; two-tailed unpaired Student's $t$-test.

overexpressed in many cancers, including laryngeal carcinoma, and is associated with their metastasis, drug resistance, and poor prognosis. ${ }^{6,731-37}$ In the present study, we investigated the role of GLUT- 1 in $\mathrm{CD} 133^{+}$laryngeal carcinoma cells under hypoxic and low-glucose conditions.

A stressful extracellular microenvironment, such as hypoxia or low glucose, may upregulate GLUT-1 expression. ${ }^{38}$ Indeed, hypoxia promotes the proliferation, migration, and chemoresistance of CSCs. ${ }^{4-7,14,15}$ In this study, the growth and migration of $\mathrm{CD} 133^{+} \mathrm{Tu} 212$ cells were greater than those of $\mathrm{CD}_{133^{-}} \mathrm{Tu} 212$ cells under hypoxic and low-glucose conditions. Possibly, this was associated with increased mRNA and protein levels of GLUT-1 in CD133 $3^{+}$Tu212 cells. These findings are consistent with previous reports that high GLUT-1 expression facilitates glucose uptake to meet the energy demand of cancer cells. This adaptive response enables cancer cells to overcome external stresses, such as hypoxia or nutrient deprivation, ${ }^{6,39}$ thereby suppressing apoptosis.

The levels of autophagy markers in $\mathrm{CD} 133^{+} \mathrm{Tu} 212$ cells were increased by hypoxia and low glucose, whereas GLUT-1 silencing reduced the levels of these proteins. These results suggest mutual regulation of glucose uptake and autophagy in stressed laryngeal carcinoma stem cells. Autophagy modulates various metabolic pathways, including glycometabolism. ${ }^{23}$ Hypoxia and glucose deprivation may induce autophagy, promoting glucose uptake by upregulating GLUT-1 expression to increase the glycolytic flux and maintain nutrient uptake under stress conditions. ${ }^{21-23,40-42}$ In airway progenitor cells, a lack of GLUT-1 impacts its recycling but not its expression, facilitating glucose uptake. ${ }^{41}$ In mouse embryonic fibroblasts, however, autophagy enhances glucose uptake by increasing GLUT-1 expression and promoting GLUT-1 trafficking. ${ }^{21}$ In this study, silencing of GLUT-1 decreased the levels of the autophagy markers beclin-1, Atg7, and Atg5, as well as the LC3II/LC3I ratio. However, inhibition or activation of autophagy by the beclin-1 shRNA/3-MA/CQ or rapamycin did not affect GLUT-1 expression. By contrast, rapamycininduced autophagy activation increased the frequency of apoptosis of laryngeal CSCs, consistent with reports that excessive autophagy induces cell death.

This study had some limitations. First, we did not assess the alterations of glucose metabolism, instead using GLUT-1 as a surrogate for glucose uptake. Second, we did not explore the findings using animal models. Third, the signaling mechanisms responsible for the enhanced GLUT-1 expression and autophagy in laryngeal 
carcinoma stem cells under hypoxic and low-glucose conditions warrant further investigation.

\section{Conclusions}

In summary, hypoxia and low glucose increased the growth and migration capabilities of $\mathrm{CD}_{133^{+}}$laryngeal carcinoma stem cells by enhancing the expression of GLUT-1 and activating autophagy.

\section{Abbreviations}

3-MA, 3-Methyladenine; GLUT-1, glucose transporter-1; CSCs, cancer stem cells; HNSCC, head and neck squamous cell carcinoma; ATG, autophagy-related proteins.

\section{Data Sharing Statement}

Data sharing is not applicable to this article as no datasets were generated or analysed during the current study.

\section{Ethics Approval and Informed Consent}

This study was conducted under the guidelines and with the approval of Second Hospital of Jiaxing City, Jiaxing City, Zhejiang Province, 314000, China (No. jxey-201003).

\section{Acknowledgment}

This work was supported by Basic public welfare research plan of Zhejiang Province, China (No. LGF18H130001), Science and technology plan project of Medical and health of Zhejiang province, China (No. 2018KY801), and National Natural Science Foundation of China (No. 81372903).

\section{Author Contributions}

$\mathrm{XH} \mathrm{C}$ designed the study and wrote the manuscript. JL, JT $\mathrm{Z}$ and $\mathrm{SH} \mathrm{Z}$ reviewed the literatures and analyzed results. SH $\mathrm{Z}$ designed the study and revised the manuscript. $\mathrm{J} F$ conducted the experiments. All authors reviewed the manuscript. All authors read and approved the final manuscript. All authors contributed to data analysis, drafting or revising the article, have agreed on the journal to which the article will be submitted, gave final approval of the version to be published, and agree to be accountable for all aspects of the work.

\section{Disclosure}

The authors declare that they have no competing interests in this work.

\section{References}

1. Siegel RL, Miller KD, Jemal A. Cancer statistics, 2020. CA Cancer $J$ Clin. 2020;70(1):7-30. doi:10.3322/caac.21590

2. Zhu M, Yin F, Yang L, et al. Contribution of TIP30 to chemoresistance in laryngeal carcinoma. Cell Death Dis. 2014;5:e1468. doi: 10.1038 /cddis. 2014.424

3. Fu Q, Liu P, Sun X, et al. Ribonucleic acid interference knockdown of IL-6 enhances the efficacy of cisplatin in laryngeal cancer stem cells by down-regulating the IL-6/STAT3/HIF1 pathway. Cancer Cell Int. 2017;17:79. doi:10.1186/s12935-017-0448-0

4. Wang C, Shao L, Pan C, et al. Elevated level of mitochondrial reactive oxygen species via fatty acid beta-oxidation in cancer stem cells promotes cancer metastasis by inducing epithelial-mesenchymal transition. Stem Cell Res Ther. 2019;10:175. doi:10.1186/s13287019-1265-2

5. Garcia-Mayea Y, Mir C, Munoz L, et al. Autophagy inhibition as a promising therapeutic target for laryngeal cancer. Carcinogenesis. 2019;40:1525-1534. doi:10.1093/carcin/bgz080

6. Zhong JT, Yu Q, Zhou SH, et al. GLUT-1 siRNA enhances radiosensitization of laryngeal cancer stem cells via enhanced DNA damage, cell cycle redistribution, and promotion of apoptosis in vitro and in vivo. Onco Targets Ther. 2019;12:9129-9142. doi:10.2147/OTT.S221423

7. Chen XH, Bao YY, Zhou SH, et al. Glucose transporter-1 expression in CD133+ laryngeal carcinoma Hep-2 cells. Mol Med Rep. 2013;8:1695-1700. doi:10.3892/mmr.2013.1740

8. Jang JW, Song Y, Kim SH, et al. CD133 confers cancer stem-like cell properties by stabilizing EGFR-AKT signaling in hepatocellular carcinoma. Cancer Lett. 2017;389:1-10. doi:10.1016/j. canlet.2016.12.023

9. Garg N, Bakhshinyan D, Venugopal C, et al. CD133(+) brain tumor-initiating cells are dependent on STAT3 signaling to drive medulloblastoma recurrence. Oncogene. 2017;36:606-617. doi:10.1038/onc.2016.235

10. Chen H, Zhou L, Dou T, et al. BMI1'S maintenance of the proliferative capacity of laryngeal cancer stem cells. Head Neck. 2011;33:1115-1125. doi:10.1002/hed.21576

11. Xu Z, Han X, Ou D, et al. Targeting PI3K/AKT/mTOR-mediated autophagy for tumor therapy. Appl Microbiol Biotechnol. 2020;104:575-587. doi:10.1007/s00253-019-10257-8

12. Yang H, Ni HM, Ding WX. The double-edged sword of MTOR in autophagy deficiency induced-liver injury and tumorigenesis. Autophagy. 2019;15:1671-1673. doi:10.1080/ 15548627.2019.1634445

13. Pereira DL, Dos Santos Ferreira AC, de Faria GP, Kwee JK. Autophagy interplays with apoptosis and cell cycle regulation in the growth inhibiting effect of Trisenox in HEP-2, a laryngeal squamous cancer. Pathol Oncol Res. 2015;21:103-111. doi:10.1007/s12253014-9794-6

14. Song YJ, Zhang SS, Guo XL, et al. Autophagy contributes to the survival of CD133+ liver cancer stem cells in the hypoxic and nutrient-deprived tumor microenvironment. Cancer Lett. 2013;339:70-81. doi:10.1016/j.canlet.2013.07.021

15. Zhu H, Wang D, Zhang L, et al. Upregulation of autophagy by hypoxia-inducible factor-1alpha promotes EMT and metastatic ability of $\mathrm{CD} 133+$ pancreatic cancer stem-like cells during intermittent hypoxia. Oncol Rep. 2014;32:935-942. doi:10.3892/or.2014.3298

16. Zhu H, Wang D, Liu Y, et al. Role of the Hypoxia-inducible factor-1 alpha induced autophagy in the conversion of non-stem pancreatic cancer cells into CD133+ pancreatic cancer stem-like cells. Cancer Cell Int. 2013;13:119. doi:10.1186/1475-2867-13-119

17. Yuen CA, Asuthkar S, Guda MR, Tsung AJ, Velpula KK. Cancer stem cell molecular reprogramming of the Warburg effect in glioblastomas: a new target gleaned from an old concept. CNS Oncol. 2016;5:101-108. doi:10.2217/cns-2015-0006 
18. Nazio F, Bordi M, Cianfanelli V, Locatelli F, Cecconi F. Autophagy and cancer stem cells: molecular mechanisms and therapeutic applications. Cell Death Differ. 2019;26:690-702. doi:10.1038/ s41418-019-0292-y

19. Rothe K, Porter V, Jiang X. Current Outlook on Autophagy in Human Leukemia: foe in Cancer Stem Cells and Drug Resistance, Friend in New Therapeutic Interventions. Int J Mol Sci. 2019;20(3):461. doi:10.3390/ijms20030461

20. Wang Y, Zhao H, Wang D, et al. Inhibition of Autophagy Promoted Apoptosis and Suppressed Growth of Hepatocellular Carcinoma Upon Photothermal Exposure. J Biomed Nanotechnol. 2019;15:813-821. doi:10.1166/jbn.2019.2714

21. Roy S, Leidal AM, Ye J, Ronen SM, Autophagy-Dependent DJ. Shuttling of TBC1D5 Controls Plasma Membrane Translocation of GLUT1 and Glucose Uptake. Mol Cell. 2017;67:84-95 e5. doi:10.1016/j.molcel.2017.05.020

22. Zhu L, Wu G, Yang X, et al. Low density lipoprotein mimics insulin action on autophagy and glucose uptake in endothelial cells. Sci Rep. 2019;9:3020. doi:10.1038/s41598-019-39559-7

23. Roy S, Debnath J. Autophagy enables retromer-dependent plasma membrane translocation of SLC2A1/GLUT1 to enhance glucose uptake. Autophagy. 2017;13:2013-2014. doi:10.1080/ 15548627.2017.1371397

24. Wan B, Zang Y, Wang L. Overexpression of Beclin1 inhibits proliferation and promotes apoptosis of human laryngeal squamous carcinoma cell Hep-2. Onco Targets Ther. 2018;11:3827-3833. doi:10.2147/OTT.S148869

25. Karpathiou G, Sivridis E, Koukourakis M, et al. Autophagy and Bcl-2/BNIP3 death regulatory pathway in non-small cell lung carcinomas. APMIS. 2013;121:592-604. doi:10.1111/apm.12026

26. Kim S, Kim DH, Jung WH, Koo JS. Metabolic phenotypes in triple-negative breast cancer. Tumour Biol. 2013;34:1699-1712. doi:10.1007/s13277-013-0707-1

27. Choi J, Kim DH, Jung WH, Koo JS. Metabolic interaction between cancer cells and stromal cells according to breast cancer molecular subtype. Breast Cancer Res. 2013;15:R78. doi:10.1186/bcr3472

28. Lin W, Yin CY, Yu Q, et al. Expression of glucose transporter-1, hypoxia inducible factor-1alpha and beclin-1 in head and neck cancer and their implication. Int J Clin Exp Pathol. 2018;11:3708-3717.

29. Hubbi ME, Hu H, Kshitiz, et al. Chaperone-mediated autophagy targets hypoxia-inducible factor-1alpha (HIF-1alpha) for lysosomal degradation. J Biol Chem. 2013;288:10703-10714. doi:10.1074/jbc. M112.414771

30. Coppock JD, Lee JH. mTOR, metabolism, and the immune response in HPV-positive head and neck squamous cell cancer. World J Otorhinolaryngol Head Neck Surg. 2016;2:76-83. doi:10.1016/j. wjorl.2016.05.010
31. Xi J, Wang Y, Liu HGLUT-1. participates in the promotion of LncRNA CASC9 in proliferation and metastasis of laryngeal carcinoma cells. Gene. 2020;726:144194. doi:10.1016/j.gene.2019.144194

32. Lu ZJ, Yu Q, Zhou SH, et al. Construction of a GLUT-1 and HIF-1alpha gene knockout cell model in HEp-2 cells using the CRISPR/Cas9 technique. Cancer Manag Res. 2019;11:2087-2096. doi:10.2147/CMAR.S183859

33. Luo XM, Xu B, Zhou ML, et al. Co-Inhibition of GLUT-1 Expression and the PI3K/Akt Signaling Pathway to Enhance the Radiosensitivity of Laryngeal Carcinoma Xenografts In Vivo. PLoS One. 2015;10:e0143306. doi:10.1371/journal.pone.0143306

34. Yan SX, Luo XM, Zhou SH, et al. Effect of antisense oligodeoxynucleotides glucose transporter-1 on enhancement of radiosensitivity of laryngeal carcinoma. Int $J$ Med Sci. 2013;10:1375-1386. doi:10.7150/ijms.6855

35. Luo XM, Zhou SH, Fan J. Glucose transporter-1 as a new therapeutic target in laryngeal carcinoma. J Int Med Res. 2010;38(6):1885-1892. doi:10.1177/147323001003800601

36. Zhou SH, Fan J, Chen XM, Cheng KJ, Wang SQ. Inhibition of cell proliferation and glucose uptake in human laryngeal carcinoma cells by antisense oligonucleotides against glucose transporter-1. Head Neck. 2009;31:1624-1633. doi:10.1002/hed.21137

37. Li LF, Zhou SH, Zhao K, et al. Clinical significance of FDG single-photon emission computed tomography: computed tomography in the diagnosis of head and neck cancers and study of its mechanism. Cancer Biother Radiopharm. 2008;23:701-714. doi:10.1089/cbr.2008.0510

38. Meng Y, Xu X, Luan $\mathrm{H}$, et al. The progress and development of GLUT1 inhibitors targeting cancer energy metabolism. Future Med Chem. 2019;11:2333-2352. doi:10.4155/fmc-2019-0052

39. Endo H, Owada S, Inagaki Y, Shida Y, Tatemichi M. Glucose starvation induces LKB1-AMPK-mediated MMP-9 expression in cancer cells. Sci Rep. 2018;8:10122. doi:10.1038/s41598-018-28074-w

40. Lin Z, Weinberg JM, Malhotra R, et al. GLUT-1 reduces hypoxia-induced apoptosis and JNK pathway activation. Am $J$ Physiol Endocrinol Metab. 2000;278:E958-66. doi:10.1152/ ajpendo.2000.278.5.E958

41. Li K, Li M, Li W, et al. Airway epithelial regeneration requires autophagy and glucose metabolism. Cell Death Dis. 2019;10:875. doi:10.1038/s41419-019-2111-2

42. Yan L, RAJ P, Yao W, Ying H. Glucose metabolism in pancreatic cancer. Cancers (Basel). 2019;11(10):1460. doi:10.3390/ cancers 11101460
OncoTargets and Therapy

\section{Publish your work in this journal}

OncoTargets and Therapy is an international, peer-reviewed, open access journal focusing on the pathological basis of all cancers, potential targets for therapy and treatment protocols employed to improve the management of cancer patients. The journal also focuses on the impact of management programs and new therapeutic

Submit your manuscript here: https://www.dovepress.com/oncotargets-and-therapy-journa agents and protocols on patient perspectives such as quality of life, adherence and satisfaction. The manuscript management system is completely online and includes a very quick and fair peer-review system, which is all easy to use. Visit http://www.dovepress.com/ testimonials.php to read real quotes from published authors. 